Journal

of Geography

Politics and Society

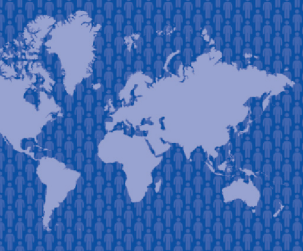

$8(2) / 2018$

\section{Journal of Geography, Politics and Society}

$2018,8(2), 44-53$

DOI 10.4467/24512249JG.18.014.8220

\title{
THE CHANGE OF TRENDS IN POLITICAL AND GEOGRAPHICAL SUBJECTIVITY OF CRIMEA
}

\author{
Alexandra Shvets (1), Igor Voronin (2) \\ (1) The Chair of Economic and Social Geography and Territorial Management, Taurida Academy (structural subdivision), Crimean Federal University of V.I. Vernad- \\ sky, Vernadsky Avenue 4, 295007, Simferopol, Russia*, \\ e-mail: fusion10@mail.ru (corresponding author) \\ (2) The Chair of Economic and Social Geography and Territorial Management, Taurida Academy (structural subdivision), Crimean Federal University of V.I. Vernad- \\ sky, Vernadsky Avenue 4, 295007, Simferopol, Russia*, \\ e-mail: voronin.igor45@gmail.com \\ * - such affiliation has been provided by the Author; according to the European Union, it is still part of Ukraine (note by the Editor-in-Chief).
}

\section{Citation}

Shvets A., Voronin I., 2018, The change of trends in political and geographical subjectivity of Crimea, Journal of Geography, Politics and Society, 8(2), 44-53.

\begin{abstract}
The article analyzes spatial indicators of changing trends in political and geographical subjectivity of Crimea. Linguistic and religious contradictions outlined Crimea among other regions of Ukraine. Limitation of linguistic diversity in Crimea, disregard towards complex contradictions between split Orthodox Christianity and politicized Islam made Crimea create background for separation from Ukrainian project of framing Russophobic state on the territory of modern Ukraine.
\end{abstract}

\section{Key words}

political geography, conflict, region, Crimea.

\section{Introduction}

Understanding of political and geographical (geopolitical) subjectivity of a region, perceived as a territorial unity formed inside a state, is connected with the fact that regional political and managerial elite has political interests and opportunities to implement them. In terms of political and geographical subjectivity of a region we point out spatial aspect that is important to economic and social geography. The sense of spatial aspect of regional political and geographical subjectivity is based on behavioral strategy typical to regional elite that can drastically change administrative and territorial status of the territory.

Not every region has its own political interests and opportunities to realize them. Political interests appear under the influence of social and cultural diversity of a region: characteristics of its geopolitical position, economic and military potential, traditions of international and domestic policy of the state which a region is a part of, peculiarities of population identity. Political interests form long-termed trends of regional development that can differ from general 
state ones. In such a case a region strives either to become autonomous inside a state or creates background for regional separatism. Autonomy in a unitary country is not recognized as a state formation and its political subjectivity is significantly limited.

For more than a quarter of a century the pendulum "autonomy-separatism" was a steady trend in the modern history and geography of Crimea inside Ukrainian state. Any movement of this pendulum to some extent affected not only general Ukrainian political situation but could cause biased reaction of the world's community. As a proof we can mention the fact of specific economic sanctions that the USA and Europe established against not only Russian Federation but particularly against the Republic of Crimea and Sevastopol. These sanctions are like punishment for political and cultural orientation of Crimea towards Russia demonstrated by its residents in 2014 during the referendum of regional identity.

Reunion of Crimea (further saying Crimea we mean the geographical unity of administrative formations - the Republic of Crimea and Sevastopol) with the Russian Federation interrupted paradoxical trends of the regional development as a territorial autonomy inside a unitary state which Ukraine is according to the Constitution. The new sense of political and geographical subjectivity of Crimea is determined by its inclusion into the system of Russian federalism. For Crimea, being limited by economic and political sanctions from Western countries, to be a part of the federation means refusal from international political ambitions (they are implemented by reunion with Russia) and focusing on the rational unification of state and local interests. Change from the trend "autonomy" to the process of federalization creates for the Crimean political and managerial elite a so-called situation of "error correction" and dealing with the risks of the time when administratively Crimea was a part of Ukraine. Geographers can identify spatial indicators of such risks.

The purpose of this article is to analyze spatial indicators that allow defining possible risks of regional political and geographical subjectivity change.

The fundamental method to determine possible risks of regional political and geographical subjectivity change is based on monitoring (content-analyzing) social and cultural conflicts featured in printed and electronic types of mass media.

Grounding the nature of social and cultural conflicts, one should imagine a society that produces competing systems of values. In social and cultural conflicts it is difficult to find reasons of collision from each competing part. Thus it is hard to classify these competing parts as "positive" or "negative". Any conflicting part protects its "own" system of values in contrast to the "other" one, often dictated by powerful elite of the society that initiates conflicts. Social and cultural conflicts in the sphere of ethnical and religious relationship between members of territorial communities are the most common ones.

The author's methods of passporting social and cultural conflicts (Швец, 2007; 2008) allowed analyzing situation of conflicting behavior in the sphere of religious relationship within Ukrainian and Crimean regions.

Passporting of social and cultural conflicts is supplied with cartographic interpretation of its territorial demonstration in Ukraine.

\section{Crimea in the context of Ukrainian regionalism}

Discussions about the essence of the Ukrainian regional space were conducted in the academic community of Ukraine throughout all the years of independence. The content of the disputes was framed around the postulate that the regions of Ukraine are really diverse, but this diversity is natural, characteristic of many countries of the world and does not fragment, but strengthens the country.

To prove this postulate, the idea of the essence of Ukrainian independence was employed. This idea had many facets, but its regional component manifested itself in the desire of the political and administrative elite to see the country united in everything: language, religion, interpretation of the history of Ukraine as identical with the history of the national movement, in the perception of the world as a copy of Western rather than the Slavic-Orthodox civilization. These aspects were the basis for the integration mechanism aimed at attracting Ukrainian regions, which was created as a part of the ideology of establishing independent Ukraine.

The reality of the regional context of Ukrainian independence turned out to be more complicated. The postulate on Ukraine's unity was refuted by the practice of electoral preferences of its residents. Western, central, eastern and southern regions of Ukraine voted from year to year in the elections not for the ideological tracing of the integrators of the country, but for candidates defending the pro-Ukrainian or pro-Russian identity of their territories. It is the electoral geography of Ukraine that has revealed in the country the phenomenon of the irresistible diversity of its regions, encountering the centralist practice of creating a monolithic unity of the country.

The geographers of Ukraine were interested in the discussion of the problem because the spatial method of research allowed proving or refuting 
the regional monolithic nature of Ukraine. In this respect, the work of M. Dnistriansky "Ethnopolitical Geography of Ukraine" (Дністрянський, 2006), rich in a variety of cartographic material proving the existence of different Ukraines, can be seen as a significant contribution of the Ukrainian geographers to the discussion of the regional originality of the country. However, the above monograph, relying on an objective cartographic interpretation of the regional ethno-political diversity of the Ukrainian regions, has many signs of the author's adherence to the idea of a monolithic unity of Ukraine and its ethno-cultural integrity, which reflects the essence of the "unitaristic" point of view in the debate about the fragmentation of the Ukrainian regional space.

In 2001, Ukraine adopted the first Concept of State Regional Policy (Указ Президента України.., 2001). It turned out to be inoperative and seven years later a new concept of regional development of the country appeared, which subsequently was periodically changed and supplemented. Ukrainian geographers in 2008-2010 tried to embed their point of view into the ideology of the state regional policy (Бортник, Олещенко, 2008; Багров et al., 2009). The meaning of the proposal of geographers was to ascertain the well-known fact about the structural reorganization of the world geopolitical order under the influence of two differently directed, opposing trends - globalization and regionalization. It was noted that regionalization had affected Ukraine. Therefore, the role of the regions became for Ukraine not only the factor of a stable economy, but also of national independence (Багров, 2010). Among the actual geographical concepts that can enhance the effectiveness of state regional policy, the concept of sustainable development of the territory was defined. Its practical implementation was to ensure (and in our conviction, did not do so) "a holistic development of the state taking into account regional peculiarities" (Бортник, Олещенко, 2008, p. 103).

The issues related to Crimea occupied a very important position in the regionalist discussion in Ukraine. That was represented in works that had an explicit or implicit reference to the idea of federalization of the country. Federalism as a political project and the goals of development of Ukraine, aspiring to the European geopolitical space, is most fully described in the work of the Crimean historian A. Malgin "Ukraine: Sobornost and Regionalism" (Мальгин, 2005). The author of this monograph considered the possible federalization of Ukraine as a variant of its integration into the European community of countries, considering federalism as "democracy in space". At the same time, he noted that by the end of the 20th century the historical space of Ukraine had changed. There appeared territories with a high proportion of ethnically non-Ukrainian population (Crimea, a number of territories of Donbass, Transcarpathia, Northern Bukovina). Consequently, the modern context of Ukrainian sobornost transformed from the unity of ethnic Ukrainian lands to the problem of the unity of the multinational regions of the Ukrainian state. This new content of sobornost is often in conflict with the traditional one.

Political and geographical subjectivity of Crimea was widely studied in the works of geographers and political scientists up to 2013. The works of N. Bagrov (Багров, 2002), O. Gabrielyan (Габриелян, 2000), V. Grigoriants (Григорьянц et al., 2011), S. Kyseliov (Киселёв, 2006, 2008), A. Malgin (Мальгин, 2000), A. Nikiforov (Никифоров, 2003, 2012), A. Shvets (Швец, 2011), А. Shevchuk (Шевчук, 2013), А. Yаkovlev (Яковлев, 2013) lay the foundation for the formation of the political and geographical conflictology school in Crimea. The above-mentioned researchers in different historical periods defined Crimea as a "nervous knot" of Ukraine's geopolitical system, a region located on the "geopolitical break of the state plates", "geovolcanic region", a territory that violates the isotropic socio-cultural space of Ukraine. After the events in Ukraine in 2014, all these definitions were to some extent justified. At the same time, the rapid pace of transformations of the regional development of Ukraine and Crimea in 2013-2016 has not still been fully comprehended by the Crimean geographers. We should note the depth of the inferences on the Ukrainian and Crimean transformations expressed in the monograph of the Moscow colleagues O. Vendina, V. Kolosov, F. Popov, A. Sebentsov (Вендина et al., 2014) as well as in the articles and dissertation by D. Olifir (Олифир, 2014, 2015). The works of the political scientist $A$. Baranov (Баранов, 2015a, 2015b) seem remarkable due to their original approaches to the analysis of the current political and geographical subjectivity of Crimea.

The dissimilarity of Crimea to the other Ukrainian regions is multifacet. Geographer S. Kyseliov (Киселёв, 2006) formulated five postulates of the Crimean regional identity: natural (features of the geological structure of the Crimean peninsula - it is not a part of the mainland, but was joined to it, high endemicity of flora, landscape diversity); ethnical (in terms of the population structure Crimea has the highest percentage of the Russians in Ukraine and the lowest percentage of the Ukrainians, there are also the natives: the Crimean Tatars, the Krymchaks, the Karaites); historical (over-saturation of the territory with historical and cultural monuments, giving 
birth to local patriotism and regional identity); economic (specialization of the region on recreational services, creating the privileged status of the Crimean residence permit); political (the base of the Black Sea Fleet of the Russian Federation, possession of nuclear weapons, the repatriation and resettlement of the deported nationalities, the Russian language widespread usability). Ignoring the objective attributes of the regional identity of Crimea by the central government of Ukraine, the attitude towards the region as a peripheral part of the country became one of the many factors of the 2014 spring events.

Crimean researchers of the Crimean regional diversity, among which there was a geographer and one of the initiators of the Crimean autonomy, who held the post of the Chairman of the Supreme Council of the Crimean ASSR in 1991-1994, an academician of the National Academy of Sciences of Ukraine Nikolay Bagrov, did not deny the idea that the existence of the Crimean autonomy is an outstanding achievement of the young Ukrainian statehood (Багров, 2002). However, without taking into account the peculiarities of the historical process in the regions, any achievements of the autonomy may appear underestimated. N. Bagrov (Багров, 2003) and O. Gabrielyan (Габриелян, 2000) proved that idea on the example of the interaction of the Ukrainian center with the regional authorities of Crimea. The overall trend of this interaction was confined to limiting the autonomy of Crimea.

The problem of limiting Crimean political subjectivity was raised in many literary resources, analyzed in detail by A. Malgin (Мальгин, 2000) and V. Grigoriants et al. (Григорьянц et al., 2011). Since Crimea gained autonomy in 1991 Ukraine did not want to accept it as an integral part and a state, the idea of which was documented in the Constitution of the Republic of Crimea in 1992 (Габриелян, 2000). The Ukrainian center constantly criticized the Act of Independence of the Republic of Crimea and some provisions of its Constitution, which further led to the elimination of the presidency in Crimea. By the beginning of the 21st century, Crimea had lost its legislative and budgetary powers, independence in the formation of judicial, law enforcement agencies and local government bodies. Instead it received the Institute of the Representative Office of the President of Ukraine, which ensured the implementation of the Constitution and laws of Ukraine. The region actually turned into an administrative area of Ukraine, endowed with some special rights.

It should be noted that the curtailment of the political subjectivity of Crimea was partly triggered by the adventurism of the Crimean political leaders who came to power in 1994. Their pro-Russian sentiments, bordering on frank separatism, consolidated the Kiev center tradition of political deterrence and mistrust towards any authority in Crimea during the period of 1994-1998.

\section{Sociocultural conflict as a marker of public discomfort}

Among the reasons that led to the desire of Crimea to change its political and geographical subjectivity in 2014-2015, we singled out those associated with the growth of socio-cultural discomfort in the regional community. The state of socio-cultural discomfort arises when the authorities try to reform the basic values of the society. For the residents of Crimea, the policy of the Ukrainian authorities regarding the Russian language and solving some ethno-religious problems was a painful reformatting.

The issue of the Russian language functioning as a regional one and, in fact, the second state language in Crimea, was recorded in 2012 by the Law of Ukraine 'On the Basics of the State Language Policy' (Закон України..., 2013). 77 per cent of the population of the Autonomous Republic of Crimea and 90.6 percent of Sevastopol residents who, according to the 2001 All-Ukrainian population census (Языковой состав населения Автономной Республики Крым..., 2001; Языковой состав населения Севастопольского горсовета..., 2001) called themselves Russian language natives, demonstrated an extremely negative reaction and protested against the decision to abolish the above mentioned law by the Verkhovna Rada of Ukraine emergency meeting on February 23, 2014 (Верховна Рада України..., 2014). Without going into the analysis of the legal aspects of the imperfections of the law on languages, it is necessary to note that for the Russian-speaking population of Crimea the attempt to abolish the law on the hot wave of events that followed the socalled "revolutionism in Kiev" was perceived as the desire of the new government to change linguistic autonomy of the South and East Ukrainian regions. In Simferopol, on February 25, 2014, a protest began with a demand not to recognize the new Ukrainian government and its laws.

The attack on Russian language in Crimea was activated at the turn of 2003-2004. This is an important marker of the newest history of Ukraine. In 2003, the anti-Russian vector was publicly identified in the political process of the Ukrainian state. The confirmation of that fact was the concept of 'Ukraine is not Russia', formulated by President L. Kuchma (Кучма, 2003) and subsequently manifested in the actions of 
Ukrainian politicians of the highest echelon of power with varying degrees of intensity.

In the policy of distancing from Russia the Ukrainian state used two channels: linguistic and religious, which are the most important for the formation of the ethnic identity. In 2004, the process of Ukrainization took its rise in the linguistic space of Crimea. According to the Crimean Ministry of Education in 2003, there were 457 Russian-language schools in Crimea (excluding data from the city of Sevastopol), in 2004 their number decreased to 435, in 2005 - fell to 414 , in 2006 it dropped to 393, in 2007 - there were only 378 schools, 2008 their number reduced to 365 , and in 2009 it totaled 340 (Киселёва, 2010). In the same period negative dynamics was observed in Russian-speaking classes and the number of pupils studying in Russian. The number of Russianspeaking classes decreased by 25 percent between 2003 and 2009, and the number of pupils in classes and schools with the Russian language of instruction reduced by 37 percent.

The process of quantitative increase in schools with the Ukrainian and Crimean-Tatar language of instruction was in progress at the same time in the Crimean educational system. By 2009 the number of Ukrainian schools increased from 4 to 8 (one of them was in Sevastopol), and with the Crimean-Tatar language - from 12 to 15 . The Ukrainian center often drew attention to the inequality in the number of Russian and Ukrainian schools in Crimea, thus refuting the thesis on prospects of imposing restrictions by Ukrainian legislation on the free use of the Russian language on the peninsula. Note that the Crimean schools were Russian only in terms of the language of teaching and communication. All curricula, as well as textbooks, were compiled and approved by the Ukrainian state bodies. For this reason, Russian-language schools in Crimea could have been considered to be Ukrainian schools.

Our analysis of the facts of the religious contradictions in the Ukrainian society, which took place in 2000-2010 and were featured in the printed mass media of Ukraine (228 cases), showed that during this period Crimea was one of four centers of religious instability (Fig. 1). Along with Crimea, centers of religious instability were formed in L'viv and Lugansk regions as well as in Kiev. These regions during the marked decade had more than 20 disputes, connected mainly with the property claims between the parishes of Christian religions. Crimea accounted for 69.2 percent of all cases of religious disagreement within the decade. But unlike other regions of Ukraine, Crimean contradictions were formed not

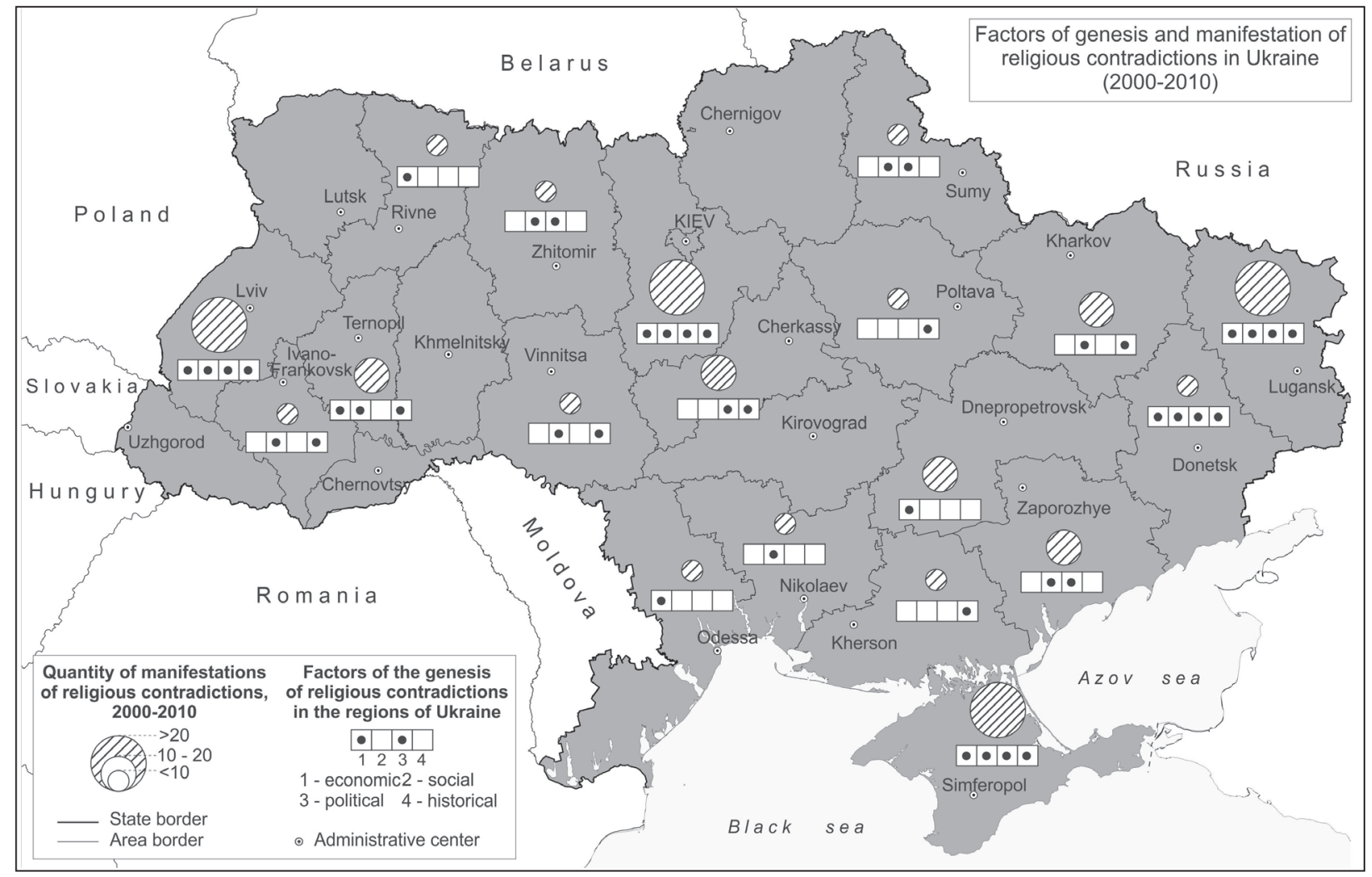

Fig. 1. Factors of the genesis and manifestation of religious contradictions in Ukraine (2000-2010)

Source: Own studies based on the analysis of the Ukrainian mass media. 
only within Christian confessions, but also between Christianity and Islam.

The first signs of the growing religious contradictions in Crimea appeared after 1995. Before that time, there was a so-called "religious renaissance" on the peninsula: the number of religious communities in Orthodoxy and Islam grew, new churches and mosques were built, religious education and pilgrimage-missionary activity developed. In 1995, on the peninsula, a formal alternative to the monopoly influence of the Ukrainian Orthodox Church (Moscow Patriarchate) appeared - two first communities of the Ukrainian Orthodox Church (Kyiv Patriarchate) - UOC (KP) were established.

The UOC (KP) is a religious organization that calls itself Orthodox, local and autocephalous church of Ukraine. It has no official recognition from the world Orthodoxy and it is not in eucharistic communion with any of the canonical local Orthodox Churches of the world. It arose as a result of the unification of two church groups that advocated independence from the Ukrainian Orthodox Church (Moscow Patriarchate). In Ukraine, the UOC (KP) claims to be a "state" or "national" church, supporting the aspiration of the modern Ukrainian state to the European Union and NATO, sharply reproving the events of the Holodomor, thus forming a particular point of view on the issue, or so-called 'mental fixations', which however are not shared by the majority of the Russian-oriented Crimean population.

Considering the mental opposition to the values that are guided by the UOC, the schismatic Kyiv Patriarchate did not receive wide circulation in Crimea. Until 2014, its parishes accounted for no more than 3 per cent of the network of religious organizations in Crimea, but the ideology of creating a single local Ukrainian church that violated the canonical unity of Ukrainian and Russian Orthodoxy was introduced into the mentality of the Crimean Orthodox believers. The emergence of the communities of the UOC (KP) in Crimea was of a political nature. This confession was associated with the strengthening of the influence of pro-Ukrainian churches in opposition to the pro-Russian UOC, which is in sympathy with such mental values as rejection of the ideas of Western liberalism, support for the value complex of Slavic sobornost (unification), Russian language, etc.

The emergence of ideologues of schism in Orthodoxy in Crimea prompted the Simferopol and Crimean Diocese of the UOC to intensify its presence in the region. The diocesan leadership in 2000 agreed to erect special monuments in some populated areas in the form of one of the symbols of Orthodoxy - Memorial Crosses - free-standing Christian crosses traditionally erected at the side of the road for the believers to bow and to worship; as well as signboards at the side of the main roads, near the tourist sites with the inscriptions «Crimea is the cradle of Orthodoxy». Muslims of Crimea in the person of the Spiritual Board of Muslims of Crimea (SBMC) immediately reacted to the Orthodox action and demanded from the authorities of the Crimean Republic to stop illegal from their point of view installation of religious monuments and billboards in Crimea and dismantle the already installed illegal structures. Prior to meeting these requirements, SBMC notified of the suspension of its membership in the interfaith association of the Crimea "Peace is a gift of God". Crimean experts noted that the statement of the SBMC appeared a few days after the visit of the head of the UOC (KP), Patriarch Filaret, who was excommunicated from the church and who met the chairman of the Mejlis of the Crimean Tatar People (an organization currently banned in Russia) to express joint displeasure with attempts of positioning of "cradle of Orthodoxy" in Crimea (Григорьянц, 2003).

After the decision of the Muftiate on the withdrawal from the interfaith association "Peace is a gift of God" there followed the events that received the name "crossfall" in the media. In four settlements of Crimea memorial crosses were demolished and destroyed. Protest actions of the Crimean Tatar population caused by appearance of new crosses continued until 2004. The overall result of the "crossfall" was the legalization of a politicized strategy of inter-religious conflict relations between the Slavic Orthodox and Crimean Tatar Muslim communities of Crimea.

The history of emergence of religious contradictions in the period of the administrative and territorial entry of Crimea into Ukraine shows that their nature had a political basis in the autonomous republic. In the policy of the Ukrainian state, aimed at limiting the political and geographic subjectivity of Crimea, the central authorities needed allies. They were artificially formed in the face of the split between the two patriarchates of Orthodoxy and the Mejlis of the Crimean Tatar People, which was opposed to the Crimean authorities, and who the Spiritual Board of Muslims of Crimea cooperated closely with.

It is interesting to note that after Crimea transferred from administrative and territorial jurisdiction of Ukraine in 2014, the territorial pattern of religious contradictions in the Orthodoxy of Ukraine has changed (Fig. 2).

We analyzed the resonant cases of material and financial contradictions between the communities of the UOC and UOC (KP) concerning the unfairly held, as some religious organizations of both patriarchates believe, restitution of the former church 


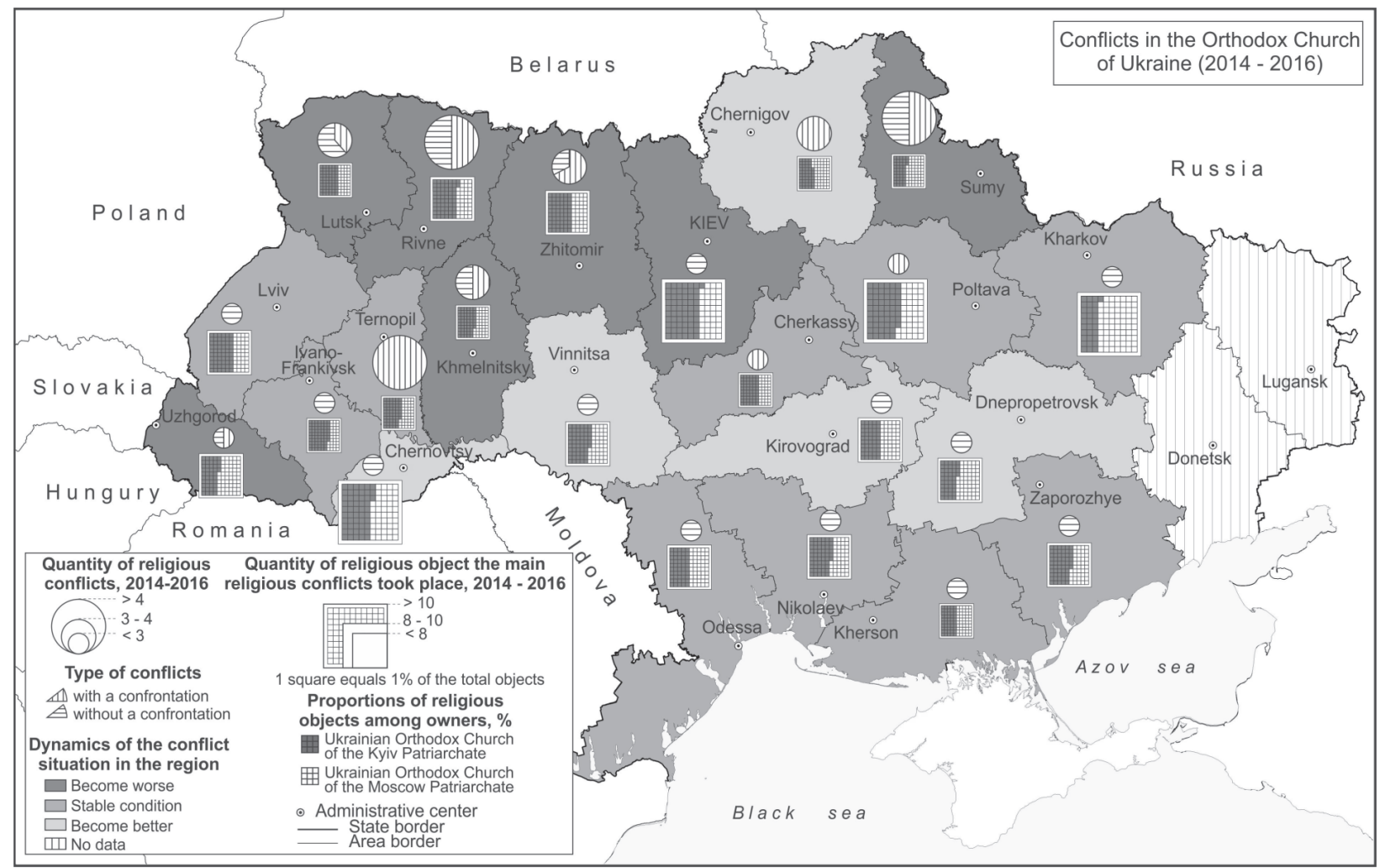

Fig. 2. Conflicts in the Orthodox Church of Ukraine (2014-2016)

Source: Own studies based on the analysis of the Ukrainian mass media

property. The restitution of church property in Ukraine which was carried out after the declaration of independence was indeed implemented without a restitution law in the country. For this reason, the return of property from the state to religious organizations gave birth to an illegal, and therefore controversial, restitution. Moreover, in the all-Ukrainian version of restitution documents, only the question of the religious buildings return has been raised, without raising the land question. The rights to receive property are not granted to monasteries, diocesan administrations, religious schools, religious communities, and missions. In Crimea, the restitution problem was complicated by the need for its legislative approval by the central authorities.

The results of our research have shown that property disputes between the Orthodox patriarchates shifted to the North (to the borders with Belarus and Russia). There they were complicated by some controversial situations not only between the UOC and UOC (KP) but also between the Ukrainian Greek Catholic Church which in the early $20^{\text {th }}$ century owned large land allotments in Volynia and Polesie region. In the South of Ukraine (on the territory of Odessa, Nikolayev, Kherson, Zaporozhe regions) property disputes acquired a stable but not a confrontational character. Here controversial situations emerge basically when building new churches. In our opinion the character of these disputes was not confrontational, in other words, it was not marked with irreconcilable forms of opposition accompanied by a human life threat.

In this religious conflict movement further to the South of Ukraine one can notice not only the danger of property disputes between confessions but also the deepening of religious schism between the regions. There is a territorial advance on the part of the divisive (dissenting) patriarchate of the UOC (KP) on the area of the prevailing influence of the UOC. The results of this advance have already been marked by sociologists.

According to a survey conducted in February 2015 by a group of sociological companies - Rating, SOCIS, Razumkov Centre and Kiev International Institute of Sociology (KIIS) the religious identification of Orthodox believers has changed in Ukraine (Вопрос веры..., 2016; Религиозные предпочтения.., 2015). It should be mentioned that Crimea and the Donbas regions which are not controlled by the Ukrainian State were not taken into consideration in the poll.

Within the Ukrainian Orthodoxy in January 1, 2017 more than 12,000 religious communities belonged to the UOC and only 4,000 - to the UOC (KP).The relative majority of the poll responders (38 percent) attributed themselves to the parishioners of UOC (KP) and nearly half as many (20 percent) 
- to the UOC (Религиозные предпочтения.., 2015; Релігійні організації в Україні.., 2017). In 2010 the described ratio was in the proportion of 34.2 and 18.2 percent respectively. Sociologists from Kiev mark that this misalignment between the number of communities and the number of believers who identify themselves as the UOC (KP) parishioners is caused by the poor awareness of respondents about the essential differences between the UOC and the UOC (KP).

Sociologists of the company Rating (Религиозные предпочтения.., 2015) mark that in the southern and eastern areas of Ukraine, except for Donbas and Odessa region, there are more supporters of the Kiev patriarchate than those of Moscow. In this regard the farther to the South and to the East the more often the respondents consider themselves simply orthodox belonging to no orthodox jurisdiction. The greatest part of these respondents turned out to be in Kirovograd, Nikolayev, Kharkov, Zaporozhe, Dnepropetrovsk, Sumy, Odessa, Donetsk and Lugansk regions. These territories constitute a kind of buffer zone between supporters of pro-Russian and anti-Russian projects of development of Ukraine. The geography of the buffer zone in Ukrainian Orthodoxy (except for Sumy region) coincides with the territories identified by us (Fig. 2) as regions of stably insignificant conflict on religious grounds.

\section{The Crimea in Russia. What next?}

The change in the political and geographical subjectivity of Crimea in 2014 allowed the region to get out of the influence of the anti-Russian concept of "Ukraine is not Russia". The new Russian reality posed the question of the future meaning of the political and geographical subjectivity of Crimea. In the mentality of the inhabitants of the republic, the trend is laid for the construction of New Crimea.

New Crimea is at present a space of disputable status. According to the official position of Ukraine and the UN General Assembly, Crimea is a temporarily occupied territory of Ukraine, and according to the official position of the Russian Federation, based on the will of Crimean residents, expressed in the March 2014 referendum, Crimea is the subject of the federal system of Russia. Thus, two mutually exclusive projects for Crimean political and geographical subjectivity are defined: the Russian and Ukrainian.

According to the Russian project, Crimea has demonstrated to the world community and the CIS countries a model of its reintegration with the large geopolitical space, namely Russia. The imperative of fitting into this great geopolitical space is to preserve its regional self-sustainability, not to turn into an ordinary Russian province.

In the Ukrainian project, Crimea is regarded as a region that violated the mythology of the existence of national and territorial unity (sobornost) of Ukraine. Such territory is subject to the various blockades: water, energy, food, transport. Relying on the sanctions support of the Western countries, the Ukrainian project is aimed at the developing of sanctions fatigue in the inhabitants of Crimea.

The future of Crimea lies with wise overcoming the obstacles created by the Ukrainian project, which pose risks to the Russian governance of Crimea. Thus, for example, the ban of the Mejlis of the Crimean Tatar People as a terrorist organization in Russia created a precedent for a split between its members into pro-Russian and pro-Ukrainian. The split provoked comicality about the aspirations of pro-Ukrainian members of the Mejlis, who, having left for Ukraine, seek to organize Crimean-Tatar autonomy there, without their own people as the bearers of its subjectivity.

\section{Conclusions}

The Crimean region proved its political and geographical subjectivity at different historic stages of development. Subjectivity is understood as a recognized by the top leaders need to make a strategy for the region development, which can change its administrative and territorial status significantly.

In 2014 Crimea proved to the whole world that it has its political and socio-cultural interests, different from those that dominated in Ukraine. The will of the people of Crimea in the referendum was the instrument that let those interests be realized. Was this decision spontaneous? No, there were too many contradictions accumulated in the autonomous subject of Ukrainian Crimea which were regarded by the Ukrainian authorities as the threat for the sovereignty. Such reluctance to take a closer look at what was happening with the ethnic and religious spheres of Crimea which were directly related to the formation of regional identity of its inhabitants became one of the channels for changing the trend of the autonomous political and geographical subjectivity of the peninsula to the federal one.

The spheres of linguistic, religious and ethnic contradictions became geographic markers of the growing socio-cultural discomfort in Crimea. In Ukraine, the Russian language was gradually supplanted from the sphere of interregional and nationwide communication, and the religious conflict was not accepted by the expert community as a catalyst 
for changing the political and geographical subjectivity. At the same time, the space of this conflict had its own poles, and Crimea was one of them. The spatial polarity of contradictions in Crimea differed from the rest of Ukraine by the presence of a multilayered - political, ethnic and religious -conflict. The religious part of this conflict reflected the discrepancy of the official ideology of the Ukrainian government aimed at building a Russophobic state and the real aspiration of the southern and eastern regions of Ukraine. The project of building the "New Crimea" within the framework of Russian federalism should be aimed at preserving the regional identity of the peninsula and shouldn't be turned into one of the peripheral parts of the Russian Federation. Such scenario of the Crimea's development is possible taking into account the risks of the Ukrainian blockade, supported by the sanctions policy of Western countries.

\section{References}

Багров Н.В., 2002, Региональная геополитика устойчивого развития, «Либідь», Киев.

Багров Н.В., 2003, Крым: время осмысления пройденного, СОНАТ, Симферополь.

Багров Н.В., 2010, Устойчиво-ноосферное развитие региона. Проблемы. Решения. Издательство ДОЛЯ, Симферополь.

Багров Н.В., Горленко И.А., Палиенко В.П., Руденко Л.Г., 2009, Основные положения концепции государственной региональной политики Украины и участие географов в её реализации, Известия $P A H$, серия географическая, 3, 18-23.

Баранов А.В., 2015b, Современный конфликт идентичностей на Украине: влияние на дезинтеграцию общества, Начиональная безопасность и стратегическое планирование, 4(12), 18-24.

Баранов А.В., 2015а, Крымско-татарское движение: тенденции конфликтности и участия в миростроительстве, Власть, 0(1), 209-212.

Бортник С., Олещенко В., 2008, X съезд Украинского географического общества, Известия РАН, серия географическая, 6, 103-104.

Вендина О.И., Колосов В.А., Попов Ф.А., Себенцов А.Б., 2014, Украина в политическом кризисе: образ России как катализатор противоречий, Полис, 5, 50-67.

Верховна Рада України ухвалила Закон «Про визнання таким, що втратив чинність, Закону України «Про засади державної мовної політики», 23 лютого 2014, http:// rada.gov.ua/print/88068.html [13.09.2017].

Вопрос веры. Украинцы и религия - сочопрос, 2016, РИА Новости Украина, http://rian.com.ua/ analytics/20161124/1018999887.html [11.09. 2017].

Габриелян О.А., 2000, Политические прочессы в Крыму. Последнее десятилетие XX века, Таврия, Симферополь.
Григорьянц В.Е., Жильцов С.С., Ишин А.В., Мальгин А.В., 2011, Федерализация Украины: кединству через многообразие, Восток - Запад, Москва.

Григорьянц В.Э., 2003, К вопросу о государственно-церковных отношениях в Украине и АР Крым, Пилигримы Крыма, 2(7), 244-269.

Дністрянський М.С., 2006, Етнополітична географія України: проблеми теорії, методології, практики, Видавничий центр ЛНУ імені Івана Франка, Львів.

Закон України від 3 липня 2012 р., № 5029-VI «Про засади державної мовної політики», 2013, Відомості Верховної Ради України, № 23 Ст.218.

Киселёв С., 2006, Пять постулатов крымского регионализма, [in:] Федерализация Украины: единство нации или распад государства? Изд-во «Европа», Москва, 37-45.

Киселёв С.Н., 2008, «Малая игра» и проблемы безопасности в Причерноморье, [in:] Проблемы безопасности Причерноморья и нейтральный статус Украины, СОНАТ, Симферополь, 68-78.

Киселёва Н.В., 2010, Язык до выборов доведёт или обещать - не значит выполнить, Крымское время, 03.09.2010, http://time4news.org/content/yazyk-do-vyborovdovedet-ili-obeshchat-ne-znachit-vypolnit [15.09.2017].

Кучма Л.Д., 2003, Украина - не Россия, Время, Москва.

Мальгин А., 2000, Крымский узел. Очерки политической истории Крымского полуострова 1989-1999, «Новый Крым», Симферополь.

Мальгин А., 2005, Украина: соборность и регионализм, СОНАТ, Симферополь.

Никифоров А.Р., 2003, Специфика Крымского региона В политическом пространстве Украины, Регіональні проекції державної політики, I, 28-41.

Никифоров А.Р., 2012, Культурно-исторический анализ украинского политического пространства, Учёные записки Таврического начионального университета им. В.И.Вернадского, серия «Философия. Культурология. Политология. Социология», 24(65)4, 244-253.

Олифир Д.И., 2014, Этнокультурный регионализм Украины: федерализация или раскол? Обозреватель, 8(295), 68-75.

Олифир Д.И., 2015, Эволюция современного регионализма Украины: экономический и этнокультурный контексты. Автореферат диссертации на соискание учёной степени кандидата географических наук, апрель 2015, Российский государственный педагогический университет им. А.И. Герцена, Санкт-Петербург.

Религиозные предпочтения населения Украины, 2015, http: //ratinggroup.ua/ru/research/ukraine/religioznye_ predpochteniya_naseleniya_ukrainy.html [6/02/2018].

Релігійні організачії в Україні (станом на 1 січня 2017 p.), 2017, RISU, https://risu.org.ua/ua/index/resourses/ statistics/ukr2017/67269/ [16/09/2017].

Указ Президента України від 25 травня 2001 р. № 341-2001. «Концепція державної регіональної політики», 2001, Офіційний вісник України, 2001 № 22 ст. 983.

Швец А.Б., 2007, География неустойчивого развития в Крыму, Геополитика и экогеодинамика регионов, 3(2), 123-130. 
Швец А.Б., 2008, Паспортизация социокультурных противоречий в Крыму, Геополитика и экогеодинамика регионов, 4(1-2), 72-80.

Швець О.Б., 2011, Географічний зміст вивчення соціокультурних конфліктів, Український географічний журнал, 3, 52-56.

Шевчук А.Г., 2013, Регионализация этноконфессиональных процессов в социокультурном пространстве Автономной Республики Крым, Этнокультурные и межконфессиональные отношения в Крыму, 3, 64-75.

Языковой состав населения Автономной Республики Крым, Основные итоги Всеукраинской переписи населения, 2001, http://2001.ukrcensus.gov.ua/rus/results/ general/language/crimea/ [6/02/2018].

Языковой состав населения Севастопольского горсовета, Основные итоги Всеукраинской переписи населения, 2001, http: //2001.ukrcensus.gov.ua/rus/results/general/ language/sevastopol/ [6/02/2018].

Яковлев А.Н., 2013, Особенности локализации социокультурной конфликтности в Крыму (2011-2012 г.г.), Эmнокультурные и межконфессиональные отношения в Крыму, 3, 43-50. 